would infringe on the freedom of choice of the individual. Nor can the argument about difficulties in enforcement be used as an excuse, since infringement is so easy to detect. When seat-belt legislation was introduced in the State of Victoria ${ }^{1}$ the majority of people complied without enforcement being necessary.

The Australian experience has a number of other useful lessons for us. It was only as a result of strong pressure from the doctors that seat-belt legislation was introduced. In Victoria all road traffic accident casualties are required by law to have a blood alcohol test taken. This has allowed a much more accurate appraisal to be made of the very significant contribution of alcohol to the road accident problem.

We may well have a good record in road accident deaths and injuries when compared with other countries. We have also made a great deal of progress in road safety. There is still so much more that we could do by relatively simple legislation and by tightening up of some of our existing laws.

Harbury, Warwicks CV33 9HG

GORDON AVERY

${ }^{1}$ McDermott, F, Annals of the Royal College of Surgeons of England, 1978, 60, 437.

\section{Rheumatoid arthritis and the gut}

SIR,-As a supplement to your leading article on rheumatoid arthritis and the gut (28 April, p 1104) I would like to report my results on the development of rheumatoid arthritis based on longitudinal investigations of several thousands of cases of infections with Yersinia enterocolitica, serotype 3.

My observations derive from an area in which $Y$ enterocolitica infections are endemic. Extensive population studies indicate that there are about 250000 new cases per year in this country. Most of them present as enteritis or mesenterial lymphadenitis or both. ${ }^{2}$ The infection is to a high degree self-limiting. Some people-and not only those of the tissue type HLA B27-develop complications of the acute intestinal infection one to three weeks later. These complications present as reactive inflammations, especially in the joints and the skin (connective tissue), but might also present as thyroid disease, glomerulonephritis, or inflammation of the eye. The complication rate is not finally settled but can be estimated as about $5 \%$. Most of the cases seen in hospital are of the arthritis types, both rather mild cases of a few weeks' duration and acute, fulminant cases of polyarthritis of severa years' duration. The latter are usually associated with the HLA B27 tissue type.

On the basis of longitudinal studies $(<8$ years) of hundreds of such cases it is now clear that some of them do not remit but-over months and years-develop into rheumatoid arthritis, some also with the development of rheumatoid factor. ${ }^{34}$ It can be estimated that such cases account for about 1 per 1000 of those with the primary infection. Longitudinal serological investigations of old-established cases of seropositive rheumatoid arthritis reveal that $Y$ enterocolitica infection is involved in more than $70 \%$ of the cases. ${ }^{35}$

With regard to the connection between HLA B27 and Yersinia infection it must be emphasised that the acute intestinal infection does not appear only in persons of this tissue type. All sorts of people and age groups, and both sexes, are involved. If a person of that tissue type, however, is infected he has a very high risk of developing a high-titre, severe arthritis, usually of long duration. If the case develops into a chronic one it will usually appear as the spondylitic type. As a whole the B27 Yersinia cases appear as the top of the iceberg of Yersinia complications.

In conclusion, it can therefore be said that my findings support the conception of rheumatoid arthritis as a primarily enteropathic arthropathy. My findings are based on observations of the effects of an established arthritogenic micro-organism, in contrast to most other aetiological observations, and they clearly demonstrate the development of an acute enteric infection into the complication of an acute reactive arthritis, which in turn develops into a chronic reactive arthritis (rheumatoid arthritis or ankylosing spondylitis). ${ }^{6}$

My hypothesis is that these findings on Yersinia infection (the Yersinia model) might be applicable to similar infections prevailing in other areas-streptococcal and Neisseria infections, salmonelloses, shigelloses, and brucelloses.

\section{JøRGEN HANNOVER LARSEN}

Department of Clinical Microbiology, Copenhagen County Hospitals,

1 Larsen, J H, Ugeskrift for Laeger, 1975, 137, 565, 570 2 Larsen, J H, Ugeskrift for Laeger, 1977, 139, 2627. Larsen, J H, Jarner, D, and

Laeger, 1977, 139, 1478 .
Jarner, D, Jarløv, N V, and Larsen, J H, Ugeskrift for Laeger, 1977, 139, 1481 .

Larsen, J H, in Infection and Immunology in the Rheumatic Diseases, ed D C Dumonde, $\mathrm{p} 133$. Oxford, Blackwell Scientific Publications, 1976.

${ }^{6}$ Larsen, J H, Contributions to Microbiology and Immunology, in press.

\section{Endoscopy for all?}

SIR,-The results of the one-visit endoscopic clinic reported by $\mathrm{Dr} \mathrm{A} \mathrm{K}$ Beavis and others (26 May, p 1387) are interesting, but perhaps optimism about such a service should be guarded.

Although Dr Beavis and his colleagues state that only $30 \%$ of the results of investigations were normal, on closer examination only in $23(12.5 \%)$ was either an ulcer or a cancer found. This is less than in our recently reported direct referral system for genera practitioners (17 February, p 457), which avoided hospital consultation altogether. Most of the other diagnostic groups mentioned are arbitrary, open to observer variation, and probably not related to symptoms. We followed up a group of such patients (see accompanying table) and found that they did not behave differently from those with completely normal findings.

Finally, it is known that investigation of dyspeptic patients is unrewarding under the age of $55,{ }^{1}$ and it is worrying that, while nearly $60 \%$ of the patients were under 45 in this study, only five out of the 205 referred to the clinic avoided endoscopy. These findings confirm ours: that is, by making endoscopy more readily available one is merely attracting the younger dyspeptic patient who previously

Six-month follow-up of patients undergoing endoscopy for dyspepsia, excluding ulcers and cancers

\begin{tabular}{|c|c|c|c|c|c|c|}
\hline \multicolumn{3}{|c|}{ Endoscopic diagnosis } & \multirow{2}{*}{$\begin{array}{r}\text { No } \\
100 \\
50 \\
50 \\
50\end{array}$} & \multirow{2}{*}{$\begin{array}{c}\begin{array}{c}\text { owith } \\
\text { ontinuing } \\
\text { symptoms }\end{array} \\
66 \\
64 \\
62 \\
64\end{array}$} & \multirow{2}{*}{$\begin{array}{c}\begin{array}{c}\% \text { on } \\
\text { antacids }\end{array} \\
52 \\
50 \\
64\end{array}$} & \multirow{2}{*}{$\begin{array}{c}\begin{array}{c}\text { Alternative } \\
\text { diagnosis }\end{array} \\
4 \% \\
4 \% \\
4 \%\end{array}$} \\
\hline $\begin{array}{l}\text { Normal.. } \\
\text { Hiatus hernia : } \\
\text { Gastritis } \\
\text { Duodenitis }\end{array}$ & $\begin{array}{l}\cdots \\
\cdots \\
\cdots\end{array}$ & $\begin{array}{l}\ddot{y} \\
\ddot{0}\end{array}$ & & & & \\
\hline
\end{tabular}

avoided investigation. There is no evidence that those patients with more sinister pathology are seen earlier in the course of their disease.

\section{GREGORY HOLDSTOCK} MARTIN WISEMAN

Professorial Medical Unit, Southampton General Hospital,
Southampton SO9 4XY

${ }^{1}$ Mead, G M, et al, British Medical fournal, 1977, 1, 1461

\section{What shall we teach undergraduates?}

SIR,-It is astonishing that in their recent article on the teaching of undergraduates (24 March, p 805) Professor V Wright and his colleagues made no mention of radiological anatomy.

Throughout a period of rapid and sometimes drastic changes in the medical curriculum, including a notable decline in the value placed on the teaching of anatomy, one crucial fact appears to have been almost universally ignored. In the same span of time there has been an enormous increase in the development and utilisation of imaging techniques of all kinds, fundamental to which is a secure basis of anatomical knowledge. It follows that the study of anatomy is not less important than was previously the case but-quite the contrary -is of greater importance than ever before. Yet the time allocated to it in some centres could now be said to approach vanishing point compared with past allocations, which ranged from five full terms to three academic years.

There seems to be a growing impression among anatomists, clinicians, and radiologists that the process of change in our medical schools may have been taken too far and too fast, for there is agreement that the general level of anatomical knowledge shown by our young graduates does not measure up to the standard required in day-to-day hospital practice. This discovery is made at least twice a year in $x$-ray departments throughout the country, whenever a new intake of house officers appear on the scene. It is all too often crystal-clear to the radiologist and his colleagues that, however well the many lists of diagnostic options have been taught and normal radiological anatomy against which possibilities can be construed as either probabilities or certainties. This order of deficiency illustrates the essential difference between training and education.

The problem is of such proportions that, in many $x$-ray departments, more queries currently arise from ignorance of radiological anatomy, of the wide range of normal appearances, and of normal variants which can simulate disease than from specific pathological conditions. A study carried out by John F Holt, director of radiology at the University of Michigan, has shown that questions concerning radiological anatomy outnumber those regarding pathological entities by three to one. ${ }^{1}$ memorised, there is no firm foundation of 